\title{
$\mathbf{J}|\mathbf{A}| \mathbf{C} \mid \mathbf{S}$ \\ COMMUNICATIONS
}

Published on Web 07/02/2002

\section{Activation of Nitrous Oxide and Selective Epoxidation of Alkenes Catalyzed by the Manganese-Substituted Polyoxometalate, $\left[\mathrm{Mn}_{2}^{\mathrm{III}} \mathrm{ZnW}\left(\mathrm{Zn}_{2} \mathrm{~W}_{9} \mathrm{O}_{34}\right)_{2}\right]^{10-}$}

\author{
Revital Ben-Daniel, ${ }^{\dagger}$ Lev Weiner, ${ }^{\ddagger}$ and Ronny Neumannn, ${ }^{*}$ \\ Department of Organic Chemistry and Chemical Services Division, Weizmann Institute of Science, \\ Rehovot, Israel 76100
}

Received February 12, 2002

Nitrous oxide is usually considered to be inert ${ }^{1}$ and a poor ligand toward transition metals. ${ }^{2}$ However, there is incentive to use $\mathrm{N}_{2} \mathrm{O}$ as an oxygen donor because it contains $36 \mathrm{wt} \%$ oxygen, and the byproduct of an oxidation reaction would be $\mathrm{N}_{2}$. In practice, there are only a few catalytic systems that have been shown to be efficient for the activation of $\mathrm{N}_{2} \mathrm{O}$ for selective hydrocarbon oxidation. In the area of heterogeneous catalysis, the most effective catalysts appear to be iron-containing acidic zeolites ${ }^{3}$ which at elevated temperatures are thought to yield surface activated iron-oxo species ( $\alpha$-oxygen $),{ }^{4}$ which are capable of oxygen transfer to inert hydrocarbons. ${ }^{5}$ Iron oxide on basic silica has been shown to catalyze, albeit nonselectively, propene epoxidation. ${ }^{6}$ In some organometallic compounds, oxygen transfer from nitrous oxide to alkyl, alkyne, and imido ligands of transition metal complexes has been observed, and metal-oxo species have been formed. ${ }^{8}$ In addition, $\mathrm{N}_{2} \mathrm{O}$ has been decomposed at subambient temperatures to $\mathrm{N}_{2}$ and $\mathrm{O}_{2}$ by a ruthenium complex. ${ }^{9}$

There is ongoing interest in oxidation catalyzed by polyoxometalates (POMs). ${ }^{10}$ Here, we describe the activation of $\mathrm{N}_{2} \mathrm{O}$ by a

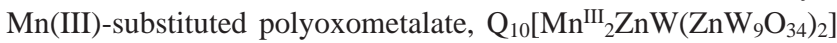
$\left(\mathrm{Q}=\left(\mathrm{C}_{8} \mathrm{H}_{17}\right)_{3} \mathrm{CH}_{3} \mathrm{~N}^{+}\right)$, Figure 1 , and subsequent highly selective catalytic epoxidation of alkenes. Previously, it was shown that $\mathrm{N}_{2} \mathrm{O}$ reacts at room temperature with a ruthenium porphyrin ${ }^{11}$ to give high valent ruthenium-dioxo species ${ }^{12}$ capable of epoxidation of alkenes. Somewhat oddly, much more extreme conditions $\left(140^{\circ} \mathrm{C}\right.$, 10 atm $\mathrm{N}_{2} \mathrm{O}$ ) are necessary for homogeneous catalytic oxidation. ${ }^{13}$

Epoxidation reactions of various alkenes catalyzed by $\mathrm{Q}_{10}\left[\mathrm{Mn}_{2}{ }_{2} \mathrm{ZnW}\left(\mathrm{ZnW}_{9} \mathrm{O}_{34}\right)_{2}\right]^{15}$ with $\mathrm{N}_{2} \mathrm{O}$ as oxygen donor were carried out in glass pressure tubes at 1 atm $\mathrm{N}_{2} \mathrm{O}$ and $150{ }^{\circ} \mathrm{C}$ in fluorobenzene as solvent. The results presented in Table 1 show that epoxides were formed at very high selectivity $(>99.9 \%)$. Typically, the reactions were rather slow, TOF $=0.5-1.4 \mathrm{~h}^{-1},{ }^{16}$ but proceeded in a linear fashion (Supporting Information), without indication of catalyst decomposition (IR). This is the first report of catalytic epoxidation with $\mathrm{N}_{2} \mathrm{O}$ with a Mn-based compound. There were only relatively small differences in the reactivity of the various alkenes; for example, the rather nucleophilic cyclooctene was only twice as reactive as less nucleophilic terminal alkenes such as 1-octene. Interestingly, trans-stilbene was slightly more reactive than cis-stilbene, and the reaction was stereoselective despite the rather high reaction temperatures. Cis- and trans-2hexen-1-ol were similarly reactive. It is worthwhile to note that other transition-metal-substituted POMs of this structure were not active (V(IV), $\mathrm{Co}(\mathrm{II}), \mathrm{Zn}(\mathrm{II}), \mathrm{Cu}(\mathrm{II}), \mathrm{Ni}(\mathrm{II})$ ) or were not selective (Fe(III) and $\mathrm{Ru}(\mathrm{III})$ ) (Supporting Information). It is also crucial to

* To whom correspondence should be addressed. E-mail: coronny@wicc. weizmann.ac.il.

$\dagger$ Department of Organic Chemistry, Weizmann Institute of Science.

¥ Chemical Services Division, Weizmann Institute of Science.

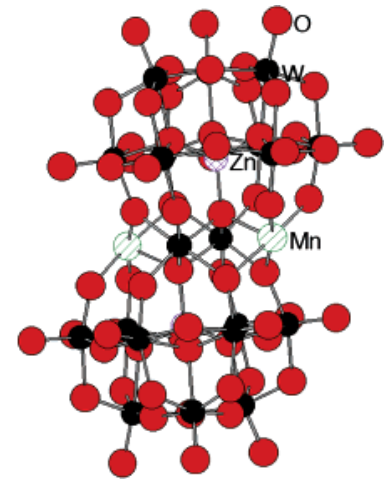

Figure 1. The $\left[\mathrm{Mn}^{\mathrm{III}}{ }_{2} \mathrm{ZnW}\left(\mathrm{Zn}_{2} \mathrm{~W}_{9} \mathrm{O}_{34}\right)_{2}\right]^{10-}$ polyoxometalate. ${ }^{14}$

Table 1. Epoxidation of Alkenes with $\mathrm{N}_{2} \mathrm{O}$ Catalyzed by $\mathrm{Q}_{10}\left[\mathrm{Mn}^{\mathrm{III}}{ }_{2} \mathrm{ZnW}\left(\mathrm{ZnW}_{9} \mathrm{O}_{34}\right)_{2}\right]^{a}$

\begin{tabular}{llc}
\hline \multicolumn{1}{c}{ substrate } & \multicolumn{1}{c}{ product } & TTON \\
\hline 1-octene & 1-octene oxide & 10 \\
trans-2-octene & trans-2-octene oxide & 14 \\
cyclooctene & cyclooctene oxide & 19 \\
1-decene & 1-decene oxide & 8 \\
cyclohexene & cyclohexene oxide & 9 \\
cis-2-hexen-1-ol & 2-hexene oxide-1-ol & 21 \\
trans-2-hexen-1-ol & 2-hexene oxide-1-ol & 19 \\
cis-stilbene & cis-stilbene oxide & 15 \\
trans-stilbene & trans-stilbene & 25 \\
\hline
\end{tabular}

${ }^{a}$ Reaction conditions: $1 \mathrm{mmol}$ of substrate, $0.01 \mathrm{mmol}$ of $\mathrm{Q}_{10}\left[\mathrm{Mn}^{\mathrm{III}}{ }_{2} \mathrm{ZnW}\right.$ $\left(\mathrm{ZnW}_{9} \mathrm{O}_{34}\right)_{2}$ ], $1 \mathrm{~mL}$ of fluorobenzene, $1 \mathrm{~atm} \mathrm{~N}_{2} \mathrm{O}, 150^{\circ} \mathrm{C}, 18 \mathrm{~h}$. TTON is total turnover number (mol product per mol $\mathrm{Q}_{10}\left[\mathrm{Mn}^{\mathrm{III}}{ }_{2} \mathrm{ZnW}\left(\mathrm{ZnW}_{9} \mathrm{O}_{34}\right)_{2}\right]$. Epoxides were formed in selectivity $>99.9 \%$ (GC). Mass balances were verified by addition of an external standard. Also, postreaction acidification of the reaction mixture showed no presence of $\mathrm{C}-\mathrm{C}$ bond cleavage products such as heptanoic acid.

note that among the Mn-substituted POMs only $\mathrm{Mn}(\mathrm{III})$ was active. No epoxidation was observed using similar Mn(II) POMs.

An a priori logical supposition concerning the mode of activation of $\mathrm{N}_{2} \mathrm{O}$ in this system would be that the $\mathrm{Mn}(\mathrm{III})$ center reacted with $\mathrm{N}_{2} \mathrm{O}$ to yield a $\mathrm{Mn}(\mathrm{V})-$ oxo species and $\mathrm{N}_{2}$. This would be followed by epoxidation, Scheme 1 , with the $\mathrm{Mn}(\mathrm{V})$ - oxo species as the latter are often viewed as active oxygen transfer agents capable of selective alkene epoxidation. ${ }^{17}$ It has already been shown that $\mathrm{Mn}(\mathrm{IV})-$ oxo polyoxometalate species are inactive in epoxidation reactions. ${ }^{18}$

Possible intermediates were investigated by ESR spectroscopy. In general, peaks for $\mathrm{Mn}(\mathrm{III})$ species $(g=8)$, and also for $\mathrm{Q}_{10}\left[\mathrm{Mn}^{\mathrm{III}}{ }_{2} \mathrm{ZnW}\left(\mathrm{ZnW}_{9} \mathrm{O}_{34}\right)_{2}\right]$, cannot be observed under usual X-band ESR conditions. ${ }^{19}$ However, when $\mathrm{Q}_{10}\left[\mathrm{Mn}^{\mathrm{III}}{ }_{2} \mathrm{ZnW}\right.$ $\left(\mathrm{ZnW}_{9} \mathrm{O}_{34}\right)_{2}$ ] was mixed at $150{ }^{\circ} \mathrm{C}$ for $4 \mathrm{~h}$ in a pressurized tube under $1 \mathrm{~atm} \mathrm{~N}_{2} \mathrm{O}$ in fluorobenzene, very surprisingly, an ESR spec- 


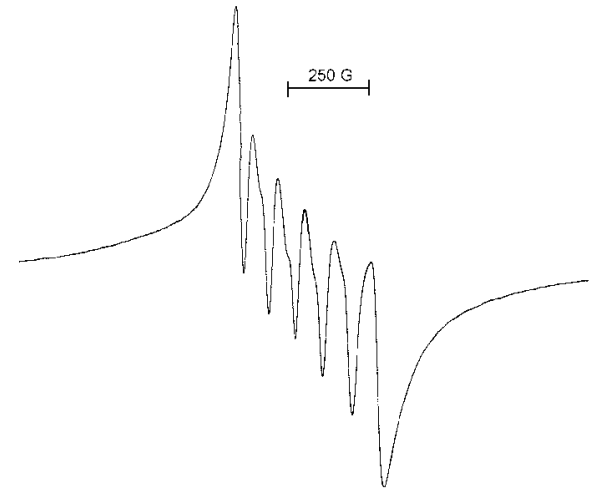

Figure 2. $\mathrm{X}$-band ESR spectrum of species obtained by reaction of $\mathrm{Q}_{10}\left[\mathrm{Mn}^{\mathrm{III}}{ }_{2} \mathrm{ZnW}\left(\mathrm{ZnW}_{9} \mathrm{O}_{34}\right)_{2}\right]$ with $\mathrm{N}_{2} \mathrm{O}$ in fluorobenzene at $120 \mathrm{~K}$.

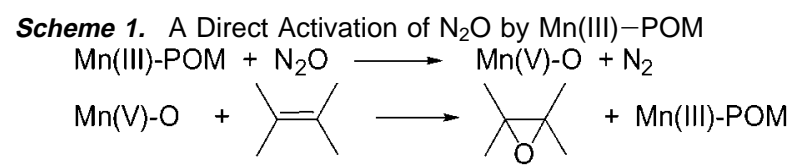

Scheme 2. A Disproportionation Mechanism for Activation of $\mathrm{N}_{2} \mathrm{O}$

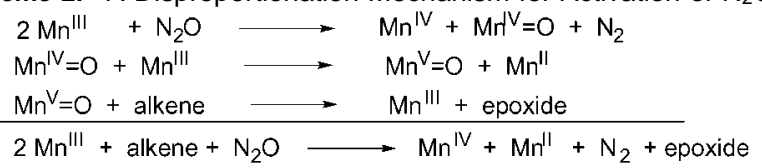

trum $(g=2.002)$, Figure 2, very typical of a $\mathrm{Mn}(\mathrm{II})$ octahedral species was obtained, ${ }^{20}$ which was also identical to the spectrum of authentic $\mathrm{K}_{12}\left[\mathrm{Mn}_{2}{ }_{2}\left(\mathrm{H}_{2} \mathrm{O}\right)_{2} \mathrm{ZnW}\left(\mathrm{ZnW}_{9} \mathrm{O}_{34}\right)_{2}\right] .{ }^{21}$ No other peaks, for example, at $g=\sim 4$, attributable to a $\mathrm{Mn}(\mathrm{IV}) \mathrm{POM}$ were observed. The $\mathrm{Mn}$ (II) concentration was significant and was estimated to be at least $70 \pm 10 \%$ of the total Mn by comparison with aqueous solutions of authentic $\mathrm{Mn}(\mathrm{II})(\mathrm{OAc})_{2}$. In the absence of $\mathrm{N}_{2} \mathrm{O}$, no ESR active species were obtained. The formation of this spectrum, however, was reversible. Thus, upon allowing the $\mathrm{N}_{2} \mathrm{O}$ to evaporate off, the ESR spectrum disappeared, and subsequent repressurization and heating again gave the observed spectrum.

To explain the formation of a $\mathrm{Mn}(\mathrm{II})-\mathrm{POM}$ species, a disproportionation mechanism could be suggested, Scheme 2 .

There are four experimental observations that appear to be incompatible with such a mechanism: (a) The formation of $\mathrm{Mn}(\mathrm{II})$ in such a scheme would not be reversible upon removal of $\mathrm{N}_{2} \mathrm{O}$ as observed. (b) There would be an immediate accumulation of $\mathrm{Mn}$ (II) in the system, but $\mathrm{Mn}$ (II)POM by itself was not catalytically active, and turnover would not be possible. (c) No $\mathrm{Mn}(\mathrm{IV})$ species were observed by ESR. (d) Vanadium(V)-containing POMs also form a monoreduced V(IV) species that, however, do not lead to epoxidation. In such a case, disproportionation is not possible.

It would therefore appear that a $\mathrm{Mn}(\mathrm{V})-\mathrm{O}$ species is not formed in this reaction system and that $\mathrm{N}_{2} \mathrm{O}$ reacts with a $\mathrm{Mn}(\mathrm{III})$ center of the polyoxometalate to reduce the polyoxometalate, while $\mathrm{N}_{2} \mathrm{O}$ is oxidized. Such a reaction is rather surprising considering the high ionization potential, $\sim 12.8 \mathrm{eV}$ of $\mathrm{N}_{2} \mathrm{O},{ }^{22}$ but may conceivably be explained by an outer sphere electron transfer, wherein the polyanionic nature of polyoxometalates energetically increases the favorability of such $\mathrm{D}-\mathrm{A}$ interactions and formation of $\mathrm{D}-\mathrm{A}$ complexes. ${ }^{23}$ An understanding of the exact nature of the activation of $\mathrm{N}_{2} \mathrm{O}$ by the $\mathrm{Mn}(\mathrm{III})$ - polyoxometalate and an explanation for the subsequent highly selective epoxidation are at this time still somewhat premature and will be the focus of future research.

Acknowledgment. This research was supported by the Basic Research Foundation administered by the Israeli Academy of Science and Humanities and the Israel Ministry of Science. R.N. is the Israel and Rebecca Sieff Professor of Organic Chemistry.

Supporting Information Available: Description of reactivity with other transition-metal-substituted POMs (Table) and reaction profile (Figure) (PDF). This material is available free of charge via the Internet at http://pubs.acs.org.

\section{References}

(1) Banks, R. G. S.; Henderson, R. J.; Pratt, J. M. J. Chem. Soc. A 1968, 2886-2889.

(2) Bottomly, F.; Lin, I. J. B.; Mukaida, M. J. Am. Chem. Soc. 1980, 102, $5238-5342$

(3) Panov, G. I. CATTECH 2000, 4, 18-32. Panov, G. I.; Uriate, A.; Rodkin, M. A.; Sobolev, V. I. Catal. Today 1998, 41, 365-385.

(4) Notte, N. P. Top. Catal. 2000, 13, 387-394.

(5) Rhodkin, M. A.; Sobolev, V. I.; Dubkov, K. A.; Watkins, N. H.; Panov, G. I. Stud. Surf. Sci. Catal. 2000, 130A, 881-886.

(6) Duma, V.; Hönicke, D. J. Catal. 2000, 191, 93-204.

(7) Mansunaga, P.; Hillhouse, G. L.; Rheinhold, A. L. J. Am. Chem. Soc 1993, 115, 2075-2077. Vaughan, G. A.; Chadwick, D.; Hillhouse, G. L.; Rheinhold, A. L. J. Am. Chem. Soc. 1989, 111, 5491-5493. Baranger, A. M.; Hanna, T. A.; Bergman, R. G. J. Am. Chem. Soc. 1995, I17, 10041-10046

(8) Conry, R. R.; Mayer, J. M. Inorg. Chem. 1990, 29, 4862-4867. Howard, W. A.; Parkin, G. J. Am. Chem. Soc. 1994, 116, 606-615.

(9) Pamplin, C. B.; Ma, E. S. F.; Safari, N.; Rettig, S. J.; James, B. R. J. Am Chem. Soc. 2001, 123, 8596-8597.

(10) Mizuno, N.; Misono, M. Chem. Rev. 1998, 98, 171-199. Hill, C. L. Prosser-McCartha, C. M. Coord. Chem. Rev. 1995, 143, 407-455. Kozhevnikov, I. V. Chem. Rev. 1998, 98, 171-198. Neumann, R. Prog. Inorg. Chem. 1998, 47, 317-370.

(11) Groves, J. T.; Roman, J. S. J. Am. Chem. Soc. 1995, 117, 5594-5595.

(12) Groves, J. T.; Quinn, R. J. Am. Chem. Soc. 1985, 107, 5790-5791.

(13) Yamada, T.; Hashimoto, K.; Kitaichi, Y.; Suzuki, K.; Ikeno, T. Chem. Lett. 2001, 268-269. Hashimoto, K.; Kitaichi, Y.; Tanaka, H.; Ikeno, T. Yamada, T. Chem. Lett. 2001, 922-923.

(14) As formed in water, the transition-metal-substituted polyoxometalates are hexacoordinate (octahedral) around the transition metal with five oxo ligands and one aqua ligand. Upon extraction to apolar solvents, the labile aqua ligand is removed, and the metal center becomes pentacoordinate (tetragonal). Neumann, R.; Gara, M. J. Am. Chem. Soc. 1995, 117, 50665074 and references therein

(15) $\mathrm{Q}_{10}\left[\mathrm{Mn}^{\mathrm{III}}{ }_{2} \mathrm{ZnW}\left(\mathrm{ZnW}_{9} \mathrm{O}_{34}\right)_{2}\right]$ was prepared by metathical exchange of $\mathrm{Na}_{10}\left[\mathrm{Mn}^{\mathrm{III}}{ }_{2} \mathrm{ZnW}\left(\mathrm{ZnW}_{9} \mathrm{O}_{34}\right)_{2}\right] \cdot \mathrm{H}_{2} \mathrm{O}$ with 10 equiv of Aliquot 336 (approximately $\left.\left(\mathrm{C}_{8} \mathrm{H}_{17}\right)_{3} \mathrm{CH}_{3} \mathrm{~N}^{+} \mathrm{Cl}^{-}\right)$. $\mathrm{Na}_{1}\left[\mathrm{Mn}^{\mathrm{III}} \mathrm{ZnW}\left(\mathrm{ZnW}_{9} \mathrm{O}_{34}\right)_{2}\right] \cdot \mathrm{xH}_{2} \mathrm{O}$ was prepared according to Tourné, C. M.; Tourné, G. F.; Zonnevijlle, F. J. Chem. Soc., Dalton Trans. 1991, 143-155.

(16) The activity of the polyoxometalate is, however, comparable per gram catalyst to that of iron oxide-basic silica (ref 6) with much improved selectivity and at much lower temperatures.

(17) Groves, J. T.; Lee, J.; Marla, S. S. J. Am. Chem. Soc. 1997, 119, 62696273.

(18) Zhang, X. Y.; Pope, M. T. J. Mol. Catal. A Chem. 1996, 114, 201-208.

(19) Campbell, K. A.; Lashley, M. R.; Wyatt, J. K.; Nantz, M. H.; Britt, R. D. J. Am. Chem. Soc. 2001, 123, 5710-5719.

(20) This includes the modest features between the six main peaks arising from semi-forbidden transitions $\left(\Delta m_{\mathrm{I}}= \pm 1\right.$ ), cf.: Morrissey, S. R.; Horton, T E.; DeRose, V. Y. J. Am. Chem. Soc. 2000, 122, 3473-3481.

(21) Neumann, R.; Gara, M. J. Am. Chem. Soc. 1995, 117, 5066-5074. It was shown that there is no magnetic coupling between the two $\mathrm{Mn}$ (II) centers leading to distortion of the ESR spectrum.

(22) There is no exact correlation between the gas-phase ionization potential and the solution oxidation potential, which is the more relevant, but unknown, parameter.

(23) Weinstock, I. A. Chem. Rev. 1998, 98, 113-170. Khenkin, A. M.; Weiner, L.; Wang, Y.; Neumann, R. J. Am. Chem. Soc. 2001, 123, 8531-8542. JA0259077 